University of Nebraska - Lincoln

DigitalCommons@University of Nebraska - Lincoln

2004

Impact of Intraspecific Polyploidy in Andropogon gerardii (Poaceae) Populations

Kathleen H. Keeler

University of Nebraska - Lincoln, kkeeler1@unl.edu

Follow this and additional works at: https://digitalcommons.unl.edu/bioscifacpub

Keeler, Kathleen H., "Impact of Intraspecific Polyploidy in Andropogon gerardii (Poaceae) Populations" (2004). Faculty Publications in the Biological Sciences. 299.

https://digitalcommons.unl.edu/bioscifacpub/299

This Article is brought to you for free and open access by the Papers in the Biological Sciences at DigitalCommons@University of Nebraska - Lincoln. It has been accepted for inclusion in Faculty Publications in the Biological Sciences by an authorized administrator of DigitalCommons@University of Nebraska - Lincoln. 


\title{
Impact of Intraspecific Polyploidy in Andropogon gerardii (Poaceae) Populations
}

\author{
KATHLEEN H. KEELER ${ }^{1}$ \\ School of Biological Sciences, University of Nebraska-Lincoln, Lincoln 68588
}

\begin{abstract}
Andropogon gerardii populations are comprised of two (or more) polyploid forms over much of the range of the species. To understand the impact of intraspecific polyploidy, polyploid cytotypes were compared over $4 \mathrm{y}$ in native grasslands in Boulder, Colorado. Boulder A. gerardii populations averaged 59.6\% hexaploids (60 chromosomes), $35.3 \%$ enneaploids (90 chromosomes) and $5.1 \%$ intermediate (aneuploid) chromosome numbers using flow cytometry to infer chromosome numbers. Neither mean clone area nor mean annual change in clone area differed significantly between ploidy levels. Hexaploid clones produced significantly more viable seeds than enneaploids. Enneaploids are not replacing themselves, whether that is measured absolutely or relative to hexaploids. Enneaploid reproductive effort was greater than hexaploid reproductive effort in some years and they produce substantial numbers of good seeds, but those seeds rarely have enneaploid cytotypes. The populations should eventually become entirely hexaploid. In the current populations, however, enneaploids are big, vigorous and fertile individuals.
\end{abstract}

\section{INTRODUCTION}

Polyploidy within populations of a single species is relatively common (Lewis, 1980; Lumaret, 1988a; Keeler, 1997). Theoretical considerations suggest that mixed ploidy populations should be unstable, eventually fixing one cytotype (Fowler and Levin, 1984; Bever and Felber, 1993; Rodríguez, 1996a, b; Ramsey and Schemske, 1998). Low fertility of hybrids between the ploidy levels selects against establishment of new polyploids since potential mates for a new polyploid are not polyploid. Even when two polyploids are equally common and have equal fitness, models predict the elimination of one (Fowler and Levin, 1984; Husband, 2000). Nevertheless, species with multiple ploidy levels in the same population are not uncommon. Studies of intrapopulation polyploidy have generally, but not always, shown small-scale microhabitat differentiation of the cytotypes (Lewis, 1976; Felber-Girard et al., 1996; Husband and Schemske, 1998).

The pattern in grasses is similar to the pattern in Angiosperms generally. In the best-studied system, Dactylis glomerata, there is gene flow between diploids and tetraploids by way of triploids (Zohary and Nur, 1959; Lumaret, 1988b), but in populations where several cytotypes were present, fine-scale habitat differentiation was detected (Lumaret and Barrientos, 1990). Panicum virgatum, a dominant of the tallgrass prairie, has two widespread races which usually have different ploidy levels (Porter, 1966). In addition, there is a polyploid series within each race and ploidy levels from diploid to dodecaploid $(12 x)$ can co-occur (Nielsen, 1944; Eberhart and Newell, 1959; McMillan, 1959; Porter, 1966; Hultquist et al., 1997). An exhaustive study by Nielsen (1947) found no difference between diploids, tetraploids and hexaploids for agronomically important traits. Other grasses in which intraspecific polyploidy has been studied include Anthoxanthum odoratum (Hedberg, 1967), Paspalum spp. (Quarín and Fernández, 1982; Norrmann et al., 1989) and Deschampsia caespitosa (Rothera and Davy, 1986).

\footnotetext{
${ }^{1}$ e-mail: kkeeler1@unl.edu
} 
Andropogon gerardii Vitman, Poaceae, was the dominant plant of the tallgrass prairie region (Weaver and Fitzpatrick, 1934). It has two common cytotypes, hexaploid $(2 n=6 x=60$ chromosomes) and enneaploid $(2 n=9 x=90$ chromosomes $)$. Plants are obligately outcrossing (Law and Anderson, 1940; Norrmann et al., 1997; McKone et al., 1998) and the cytotypes are interfertile (Norrmann et al., 1997; Norrmann and Keeler, 2003). In the eastern tallgrass prairie, enneaploids are rare, but present (Keeler, 1990). In the western part of the tallgrass prairie region, the distribution of cytotypes is approximately $55 \%$ hexaploids, $40 \%$ enneaploids and $5 \%$ intermediate cytotypes (Keeler et al., 1987; Keeler, 1990, 1992).

The hexaploid and enneaploid are related to each other as if they were diploid and triploid. Plants with intermediate cytotypes (aneuploids with chromosome numbers 61-89) are produced in controlled crosses between hexaploids and enneaploids (Norrmann et al., 1997; Norrmann and Keeler, 2003) and occur at frequencies of $0-7 \%$ in natural populations (Keeler, 1992).

Meiosis is regular in hexaploids and highly irregular in enneaploids and aneuploids (Riley and Vogel, 1982; Norrmann et al., 1997; Norrmann and Keeler, 2003). Consequently, hexaploids produce a higher frequency of viable seeds. Under common garden conditions, enneaploid plants grow bigger than hexaploids, although visual identification of ploidy is unreliable (Keeler and Davis, 1999). Populations frequently include numerous plants of both common cytotypes (Keeler, 1992). No statistically significant relationship to environment or microhabitat has been detected (Keeler, 1990, 1992).

This study was undertaken to compare Andropogon gerardii cytotypes under natural conditions, as advocated by Lumaret (1988a). Flow cytometry allows determining cytotypes of plants in situ (Keeler et al., 1987; Michaelson et al., 1991). The study was conducted in the City of Boulder Open Space and Mountain Parks because in these tallgrass prairies, on some sites, A. gerardii plants are sufficiently scattered to allow distinguishing individuals. Initially, hexaploids were expected to be so much more fit than enneaploids that the question was whether enneaploids made any contribution at all to the population. Thus, this study was initiated to determine if enneaploid plants had increased growth or survival in situ that would explain their presence despite their low viable seed production.

\section{Materials AND Methods}

The plants studied are in permanent plots on City of Boulder Open Space and Mountain Parks land in Boulder, Colorado. The plots are in tallgrass prairie (Livingston, 1952; Branson et al., 1965; Bock and Bock, 1998). Plots were located on or near Jane and Carl Bock's permanent markers: my plot numbers conform to their system. Additional information is available from the City of Boulder Open Space and Mountain Parks and in Bennett (1997). The plots include a range of soil types and management treatments. Since Andropogon is very responsive to growing conditions (e.g., Svejcar, 1990), diverse sites allow comparison of the cytotypes, not the land management. Four plots were established in 1995, the remainder in 1996: data reported here are from 1996-1999.

Plots were originally $10 \times 10 \mathrm{~m}$ in area and contained from 22 to 268 plants of Andropogon gerardii. To improve comparisons between plots, plot 45, the densest population, was reduced in area to $80 \mathrm{sq}$. m., the rest remained at $100 \mathrm{sq} . \mathrm{m}$.

Plants were defined based on gaps separating clumps of Andropogon gerardii. In the populations studied, A. gerardii forms distinct patches and interpatch distances are in most cases several times the average annual clone expansion distance $\left(0.33 \mathrm{~cm}^{2}\right.$, Fig. 1). Comparison of the height, color, shape and phenology of plants confirmed assignment to a clone.

Cytotypes were determined using flow cytometry: fresh leaves were sent to the Flow Cytometry Facility at the University of Nebraska-Lincoln where total nuclear DNA content 


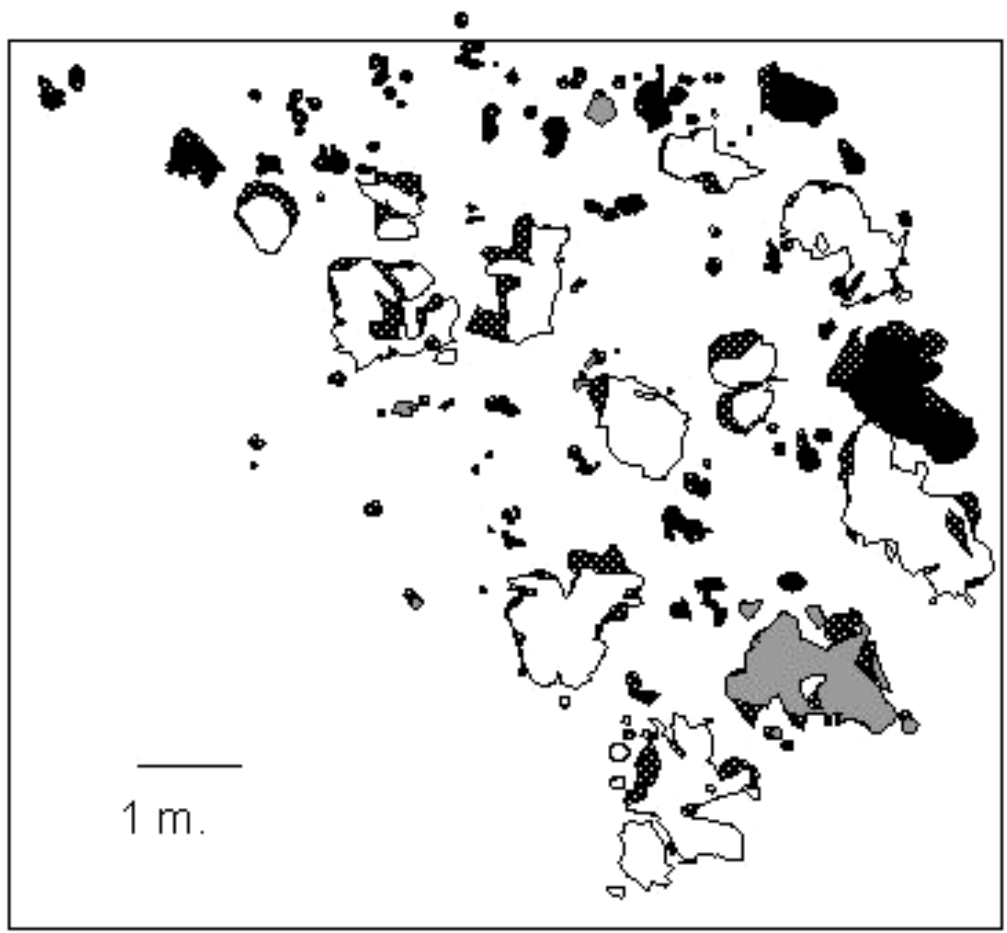

Fig. 1.-Map of Plot 45, highest density plot, showing natural gaps between plants and change between 1995 (dark stipple) and 1999 (black/gray/white). 60 chromosomes: black, intermediate: gray, 90 chromosomes, white

was determined under the direction of K. Arumuganathan (method of Arumuganathan and Earle, 1991). Propidum iodide was the stain and barley the internal standard. Under these conditions hexaploid plants give a mean of $5.93 \mathrm{pg}$ DNA $( \pm 0.5295 \% \mathrm{cl})$ per nucleus and enneaploid plants averaged $8.92 \mathrm{pg}$ DNA/nucleus ( \pm 0.48 ) (Keeler et al., 1987; Norrmann et al., 1997). Plants with DNA contents between those were taken to have intermediate chromosome numbers, as seen in crossing studies (Norrmann et al., 1989; Norrmann and Keeler, 2003) and behave as aneuploids. Plants in this study that were retested 1 to 4 y apart differed in mean DNA contents by 0.08 to $0.25 \mathrm{pg}$ DNA, or $1-4 \%(\mathrm{~N}=6)$, which is consistent with previous work on this species (Keeler, 1992).

A few plants in the areas studied were omitted because they were so small that removing a leaf for flow cytometry might have killed them; they are excluded from analysis.

Andropogon gerardii plants in the marked area were mapped to the nearest $\mathrm{cm}$. Every year the following information was collected for each plant: map position, number of seeds produced, weight of seeds produced, number and frequency of filled seeds. Clone area and change in clone area were determined from plot maps digitized into the geographic information system program ArcView (ESRI, 1997).

Several morphological characters were compared. Plant size generally increases with ploidy level, as was previously seen in Andropogon gerardii (Keeler and Davis, 1999). This was considered in this population by measuring the maxiumum leaf length and leaf width. 
To compare reproductive effort and success, the number of flowering stalks, number of racemes and number and mass of fertile and sterile spikelets (containing the single-seeded fruits and the seeds) produced were determined. These measures were found to correlate tightly to each other ( $\mathrm{see}$ Results). All spikelets produced by marked plants were gathered at the end of the growing season and weighed to the nearest $0.01 \mathrm{~g}$.

Andropogon gerardii frequently produces large numbers of fertile spikelets that do not contain a seed (Masters et al., 1993). Thus, number and percent of seeds in the spikelets were carefully determined. First, fertile spikelet mass was weighed and the number of fertile spikelets counted. If there were fewer than 100 on the plant, all spikelets were checked for seeds: each was opened to see if a seed was inside. Most full-sized seeds germinate ( see below). "Good seeds" are thus oval, plump and brown. For large spikelet masses, the number of seeds produced by the plant was estimated by multiplying the frequency of good seeds in the sample of 100 by the total number of fertile spikelets counted from that plant. Small or broken seeds were counted separately. Plump but short seeds were considered good, flat but long seeds were not. Seed production was low enough that when in doubt I called it good. Where kernel smuts (Sphacelotheca occidentalis) occurred in the seed crop, those were counted separately as well. The total number of viable seeds produced by the plant equalled the sum of good seeds plus broken seeds (presumably killed by herbivores), plus the kernel smuts, since those require seed (Snetselaar and Tiffany, 1990).

Andropogon gerardii sometimes produces seeds from the "sterile spikelets," the pedicellate spikelets, that are paired with the perfect "fertile" sessile spikelets along the raceme (Boe et al., 1983; Springer, 1991). Therefore, 100 pedicellate spikelets per plant were also checked for seeds. Across all plots, seeds were present in an average of 1 in $1.6 \times 10^{4}$ spikelets and, of those, $3.8 \%$ were contributed by pedicellate spikelets. Because they were so rare, the few seeds in pedicellate spikelets were simply included in the number of viable seeds. Percent viable seeds, thus, represents seeds from sterile plus fertile spikelets divided by number of fertile spikelets checked, times 100 .

The data do not have a normal distribution: each year many plants did not send up a flower stalk and most plants produced no viable seeds. The relationship of seed production to ploidy was tested by coding flowering attempts as 0 or 1 and comparing in a contingency table. The same approach was used to compare the incidence of successful seed production between ploidy levels: seeds in any of the $4 \mathrm{y}$ was scored as 1 , none at all as 0 .

Viability of seeds was tested in two ways and compared between parental ploidy levels. First, individual, apparently good, field-collected seeds were stored at room temperature all winter and planted in standard soil in the greenhouse in April 1999. Number and percent germination were compared by maternal cytotype. Second, $1 \mathrm{~g}$. samples of unsorted spikelets were placed on soil in the greenhouse. The number of seedlings that emerged was compared by maternal cytotype. All available material was used and more enneaploids than hexaploids produced large numbers of spikelets that year. In 1999 seed production was too low to repeat these experiments. The distribution of cytotypes among sibships produced in the germination experiments just described was determined by measuring the nuclear DNA content using flow cytometry. I tested the first 10 seedlings in the pot, independent of seedling vigor.

Areas, change in area and seed production measures were compared between ploidy levels using repeated measures ANOVA, after square root transformation to normalize the distribution. The basic model looked at ploidy and year as fixed effects and treated plant and plot as random (SAS Mixed program SAS Institute Inc., 1999). Plant was the unit of observation and as noted above, plot was treated as random in order to focus on the effects of polyploidy. Contingency table analyses used Fisher's Exact Test. Mean number of 
TABLE 1.-Distribution of Andropogon gerardii cytotypes in Boulder CO plots in 1996

\begin{tabular}{llllccrr}
\hline \hline Plot & Moisture & Grazing & \multicolumn{1}{c}{ Other } & $\begin{array}{c}\text { Hexaploid } \\
\text { chromosomes }) \\
(\%)\end{array}$ & $\begin{array}{c}\text { Intermediate } \\
(61-89)(\%)\end{array}$ & $\begin{array}{c}\text { Enneaploid } \\
(90)(\%)\end{array}$ & Total \\
\hline 36 & wet & winter & Floods in spring & $22(48.9)$ & $1(2.2)$ & $22(48.9)$ & 45 \\
58 & wet & ungrazed & Floods in spring & $13(54.2)$ & $1(4.1)$ & $10(41.7)$ & 24 \\
45 & mesic & winter & Spring irrigated & $58(72.5)$ & $8(10.0)$ & $14(17.5)$ & 80 \\
102 & mesic & ungrazed & Burned 96 & $1(6.2)$ & 0 & $15(93.8)$ & 16 \\
28 & dry & summer & & $16(72.7)$ & 0 & $6(27.7)$ & 22 \\
52 & dry & winter & & $15(60.0)$ & $3(12.0)$ & $7(28.0)$ & 25 \\
57 & dry & ungrazed & Burned 97 & $9(40.9)$ & 0 & $13(59.1)$ & 22 \\
61 & dry & summer & & $30(73.2)$ & $1(2.4)$ & $10(24.4)$ & 41 \\
& Totals (\%) & & & $164(59.6)$ & $14(5.1)$ & $97(35.3)$ & 275 \\
\hline
\end{tabular}

seedlings per maternal parent was compared with Mann-Whitney U test. Statistical analysis used the StatView 5.0 and PC SAS programs (SAS Institute Inc., 1999).

\section{RESULTS}

A total of 275 plants of Andropogon gerardii were mapped and cytotyped within eight plots in the City of Boulder Open Space and Mountain Parks, Boulder, Colorado. Of those, 164 $(59.6 \%)$ were hexaploid, $14(5.1 \%)$ had intermediate chromosome numbers and 97 $(35.3 \%)$ were enneaploids (Table 1$)$. Frequency of hexaploids within plots ranged from $6-$ $73 \%$ (Table 1). This distribution is similar to the distribution of cytotypes at Konza Prairie, Manhattan, Kansas, both in the overall mean and in the wide range of variation between plots (Keeler, 1992).

One additional plot [Bocks' Plot 7, see Bennett (1997)] contained only hexaploid plants, 18 of them. It has been omitted from further analysis because it could not be used to compare response of the different ploidy levels in a shared microhabitat. With the addition of this plot, the City of Boulder Open Space and Mountain Parks have $63.9 \%$ hexaploids, $4.6 \%$ intermediate cytotypes and $31.5 \%$ enneaploids.

Intermediate cytotypes are included throughout the analysis. However, they are rarely significantly different from the other cytotypes because they are highly variable. Intermediate cytotypes produced in controlled crosses were likewise sometimes very fertile and vigorous, sometimes very weak (Norrmann et al., 1997; Norrmann and Keeler, 2003).

The effect of plot management on Andropogon gerardii was generally statistically significant. Controlled burning, winter grazing and irrigation all improved A. gerardii growth and flowering. These effects have been repeatedly documented (e.g., Svejcar, 1990). No significant difference between cytotypes has been detected (Keeler, 1992; Keeler and Davis, 1999). These responses to burning and grazing occurred in the plots studied here, but they were not the focus of the study.

\section{Clone Size Comparisons}

Clones ranged in area from $4.5 \mathrm{~cm}^{2}$ to $99,380 \mathrm{~cm}^{2}$. The mean clone area of hexaploid plants was $2910 \mathrm{~cm}^{2}$ (SE 692), of intermediate cytotypes 2450 (SE 1302) and of enneaploids 3191 (SE 528). The mean areas of the different ploidy levels are not significantly different (repeated measures anova, including plot as a random variable $\mathrm{F}=1.37, \mathrm{P}=0.25$ ) and there was no significant effect of year or year*ploidy $(\mathrm{F}=0.06, \mathrm{P}=0.99)$. 


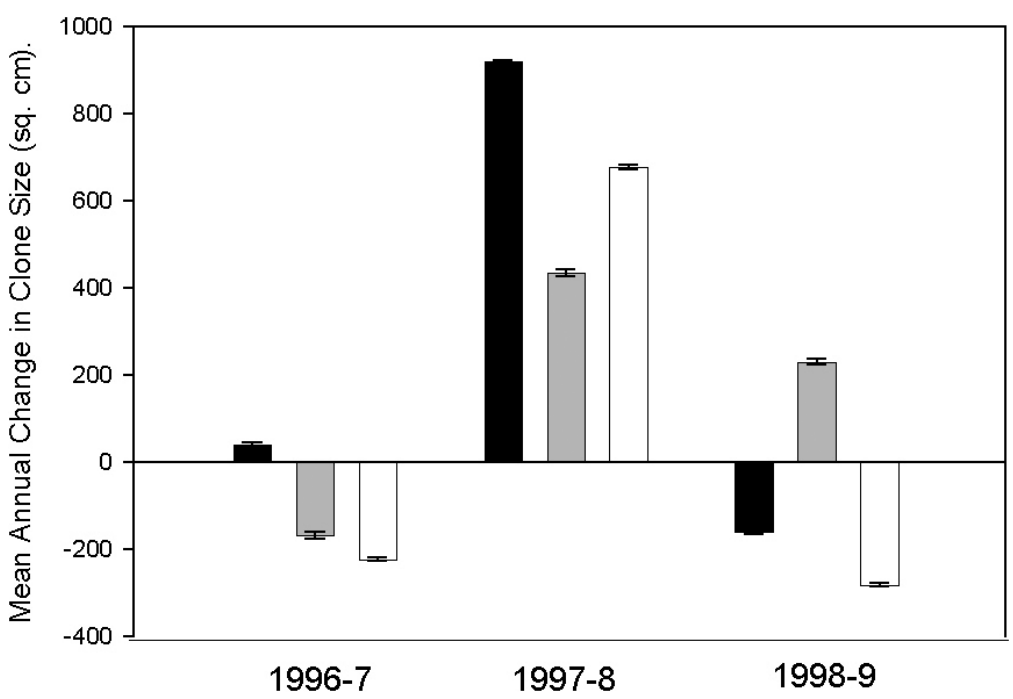

Fig. 2.-Mean annual change in area, in sq. $\mathrm{cm}$. Hexaploid black $(\mathrm{N}=146,145,143)$, intermediate gray $(\mathrm{N}=12)$, enneaploid white $(\mathrm{N}=91,91,90)$. Error bar is $1 \mathrm{SE}$

Mean annual change in area for hexaploids was $278 \mathrm{~cm}^{2}$ (SE 137), intermediates 166 (SE 72) and enneaploids 69 (SE 54) (Fig. 2). Repeated measures ANOVA, including plot as a random variable, showed no significant effect of ploidy $(\mathrm{F}=0.81, \mathrm{P}=0.47)$. Year had a significant effect of the size change $(\mathrm{F}=13.4, \mathrm{P}<0.001)$, but the interaction with ploidy was not significant $(\mathrm{F}=0.89, \mathrm{P}=0.47)$. When mean clone expansion was corrected for area of clone (Fig. 3), there was no significant effect of ploidy (ANOVA of normalized data, using plot as

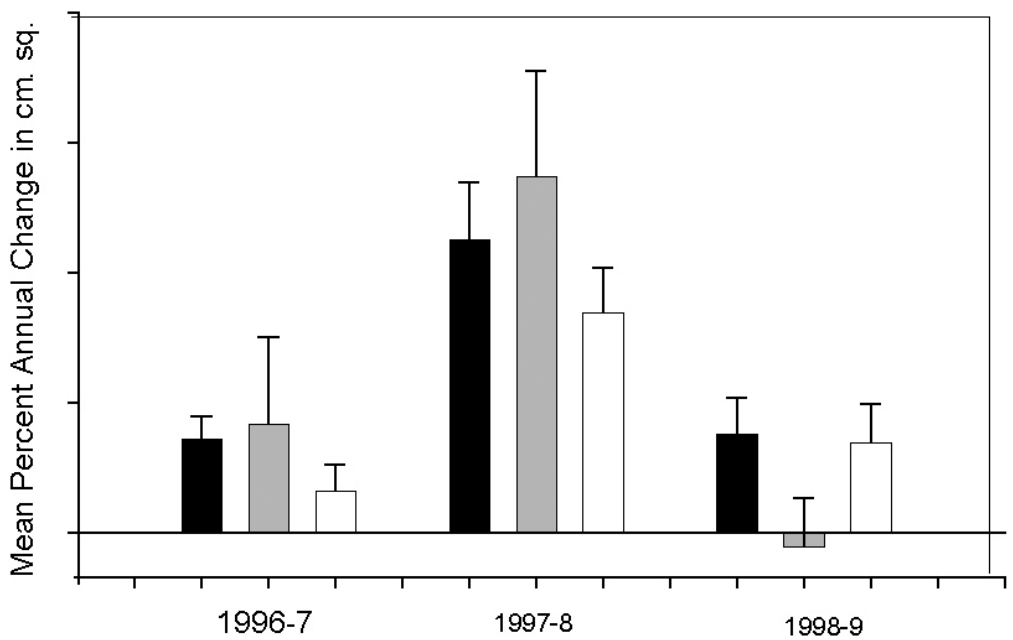

FIG. 3.-Mean percent change in clone size, as a function of initial clone size. Hexaploid black $(\mathrm{N}=$ $147)$, intermediate gray $(\mathrm{N}=12)$, enneaploid white $(\mathrm{N}=93)$. Error bar is $1 \mathrm{SE}$ 
a random variable $)\left(\mathrm{F}_{\text {ploidy }}=2.53, \mathrm{P}=0.08, \mathrm{df}=2,236, \mathrm{~F}_{\text {year }}=2.03, \mathrm{P}_{\text {year }}=0.13, \mathrm{~F}_{\text {ploidy } \times \text { year }}=\right.$ $1.57, \mathrm{P}=0.18$ ).

\section{Vegetative Comparisons}

Maximum leaf length and width of hexaploids were significantly smaller than those of enneaploids. Mean leaf length in 1995 was $28.1 \mathrm{~cm}(\mathrm{SE} 0.3, \mathrm{~N}=77)$ for hexaploids, for intermediates $22.2(\mathrm{SE} 1.1, \mathrm{~N}=6)$ and for enneaploids $39.2(\mathrm{SE} 0.6, \mathrm{~N}=28)$. The first two are significantly different from the last, but not from each other $(t$-test, $\mathrm{P}<0.05)$. Repeating the comparison of leaf length in 1996 gave the same pattern, hexaploids 24.2 (sE $0.3, \mathrm{~N}=72$ ), intermediates 20.3 ( $\mathrm{SE} 1.0, \mathrm{~N}=7$ ) and enneaploids 28.1 ( $\mathrm{SE} 0.4, \mathrm{~N}=47$ ), hexaploids and intermediates significantly different from the enneaploids (and smaller), but not significantly different from each other $(t$-test, $\mathrm{P}<0.05)$. Leaf widths likewise were smaller in hexaploids and intermediates, (hexaploid $6.3 \mathrm{~mm}, \mathrm{SE} 0.2, \mathrm{~N}=75$, intermediates $5.9 \mathrm{SE} 2.6$, $\mathrm{N}=7$; enneaploids 7.2 SE $0.2, \mathrm{~N}=47$ ), significantly less than enneaploids, but not different from each other $(t$-test, $\mathrm{P}<0.05)$.

\section{ReProductive Comparisons}

Reproduction depends on both the effort invested in flowering and the viability of each seed and seedling.

The number of plants that produced a flower stalk at least once in the $4 \mathrm{y}$ of observation did not differ significantly between cytotypes (Fisher's Exact Test, $\mathrm{P}=0.27, \mathrm{~N}=224$ ).

Measures of flowering effort were tightly correlated. The number of flower stalks correlated positively and significantly to spikelet biomass $\left(r^{2}=0.86,0.98\right.$ and 0.91 , for 1996, 1998 and 1999 , respectively, in all cases $\mathrm{P}<0.001)$. Likewise, number of spikelets counted per plant correlated significantly with the weight of the spikelet biomass $\left(r^{2}=0.96,0.94,0.98\right.$ and 0.96 for $1996-9, \mathrm{P}<0.001$ in all cases). Consequently, spikelet number is used in further analysis.

There was no significant effect of ploidy on number of spikelets per plant, after normalizing (Fig. 4, $\mathrm{F}_{\text {ploidy }}=2.16, \mathrm{P}=0.12, \mathrm{df}=2,365, \mathrm{~F}_{\text {ploidy } \times \text { year }}=1.09, \mathrm{P}=0.41$ ) although there is a significant effect of year on seed production $\left(\mathrm{F}_{\text {year }}=4.71, \mathrm{P}=0.003\right)$.

Since many spikelets were empty $(2.7 \%$ were filled, SD 4.0$)$, and bigger plants tended to produce more spikelets $\left(\mathrm{r}^{2}=0.39, \mathrm{P}<0.001, \mathrm{~N}=225\right)$, seeds (not spikelets) was compared between plants (Figs. 4, 5). Ploidy had a significant impact on percent good seeds $(\mathrm{P}<0.001)$ as did year $(\mathrm{P}<0.001)$. The ploidy $\times$ year interaction was nonsignificant $(\mathrm{P}=0.81)$. Eliminating the zeros, the relationships were similar but weaker $\left(\mathrm{P}_{\text {ploidy }}=0.01, \mathrm{P}_{\text {year }}=0.01\right.$, $\left.\mathrm{P}_{\text {ploidy } \times \text { year }}=0.86\right)$. (Correcting for area of each plant gave the same pattern $\mathrm{P}_{\text {ploidy }}=0.02$, $\left.\mathrm{P}_{\text {year }}<0.001, \mathrm{P}_{\text {ploidy } \times \text { year }}=0.51\right)$.

Some spikelets contained seed fragments. Broken seeds could be a result of herbivory or could represent seeds spontaneously aborted due to unbalanced genomes. Frequency of broken seeds was significantly associated with cytotype (repeated measures ANOVA, F = $4.75, \mathrm{P}=0.009$ ). Hexaploids had the highest frequency of broken seeds (mean percent broken: hexaploids 1.07, SD 3.0, intermediate cytotypes 0.77 , SD 2.1, enneaploids 0.49 , SD 1.6). Since hexaploids have regular meiosis and usually the highest frequency of good seeds (Fig. 5), this is more likely due to herbivory than chromosomal abnormalities.

A few of the plants had kernel smuts during study period: 4, 4 and 5 in 1997-9, different plants each year. Thirteen were hexaploids and four enneaploids. The occurrence of kernel smuts did not differ between ploidy levels (Fisher's Exact Test, P > 0.99).

The mean number of seedlings emerging from a gram of spikelets was higher for hexaploids. In lots of $1 \mathrm{~g}$ of unsorted spikelets (thus, containing good and empty spikelets) 


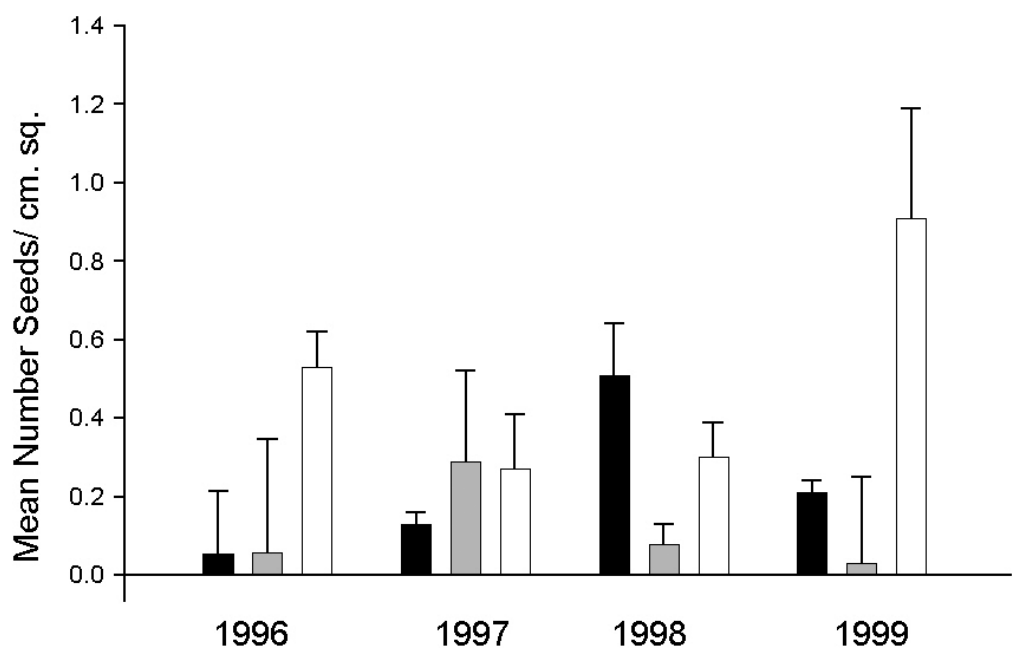

FIG. 4.-Mean number of seeds produced per sq. cm. per clone $( \pm \mathrm{SE})$. Hexaploid black $(\mathrm{N}=147)$, intermediate gray $(\mathrm{N}=12)$, enneaploid white $(\mathrm{N}=93)$

from 6 hexaploids (3-5 lots per plant), the mean number of seedlings was 35.7 (SE 35.7), while for 8 enneaploids ( 5 lots per plant) mean $=8.7$ ( $\mathrm{SE} 8.2)$. These means are significantly different, Mann-Whitney $\mathrm{U}, \mathrm{P}=0.001$. Except for one family, all the enneaploids had lower frequencies of seedlings than all hexaploids.

When a good (plump, oval, brown) seed was present, there was no significant difference between parents of different cytotypes. In the greenhouse, from 127 apparently filled and healthy seeds, 55 of 105 seeds from hexaploid plants germinated, 4 of 9 seeds from

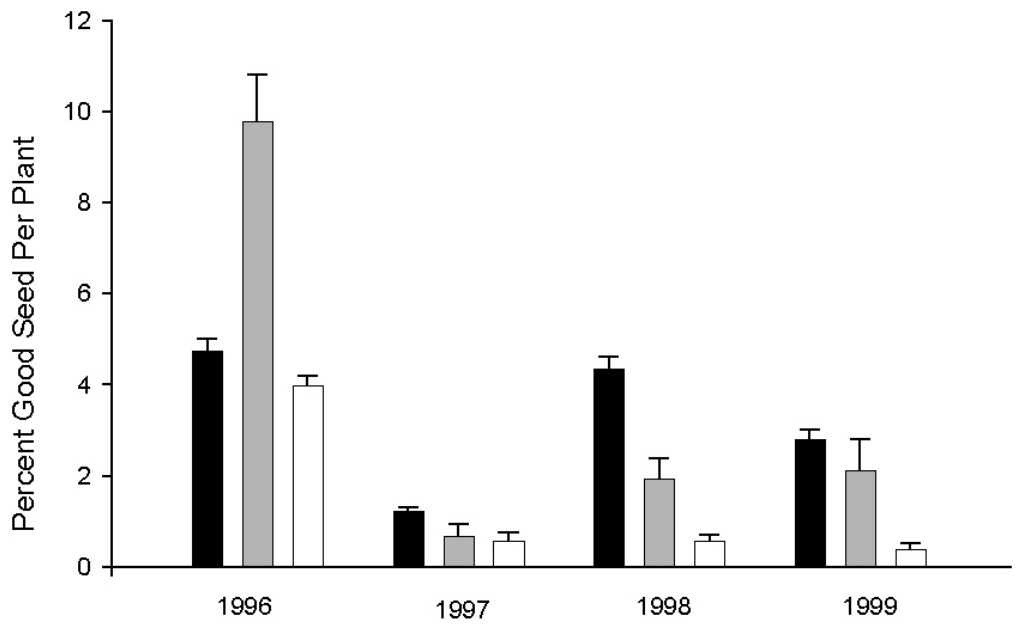

FIG. 5.-Mean percent good seeds per clone. Hexaploid black $(\mathrm{N}=136)$, intermediate gray $(\mathrm{N}=9)$, enneaploid white $(\mathrm{N}=88)$. Error bar is $1 \mathrm{SE}$ 
intermediate cytotypes and 8 of 13 seeds from enneaploid plants. These numbers are not significantly different (Fisher's Exact Test $\mathrm{P}>0.14$ for all pairwise comparisons).

Considering good seed production by all cytotypes in a year across plots, enneaploids contributed $68.0 \%$ of the good seeds in $1996,14.1 \%$ in $1997,26.4 \%$ in 1998 and $16.3 \%$ in 1999. Enneaploids are certainly part of the breeding population.

Testing the cytotypes of seedlings in comparison to the parent plant, seeds from plants of known cytotype were gathered in 1998 from the Boulder populations and germinated in the greenhouse. Ploidy was determined using flow cytometry, using the definitions (as above, Norrmann et al., 1997): 5.41-6.45 pg DNA/nucleus (97\% cl): hexaploids; enneaploids 8.44$9.50 \mathrm{pg}$ DNA $(95 \% \mathrm{cl})$, intermediates falling between. The progeny of seven hexaploid mothers were 52 hexaploid (78.8\%), 13 intermediate $(19.7 \%)$ and 1 enneaploid $(1.5 \%)$ seedlings. The progeny of the one intermediate tested (maternal DNA $=7.22$ ) were 10 hexaploids $(91 \%)$ and 1 intermediate $(9 \%)$. Four enneaploid plants produced 13 hexaploid seeds (25\%), 37 intermediate DNA seeds $(71 \%)$ and 2 enneaploid seeds $(3.8 \%)$. Thus, the hexaploid mothers had hexaploid seeds $78.8 \%$ of the time, intermediate DNA mothers had intermediate seeds $9 \%$ of the time and enneaploid mothers had enneaploid seeds $3.8 \%$ of the time. Overall this sample of 10 (and in 1 case 11) seeds from each of 12 plants (parental ratio 58: 8: 33) in the natural populations yielded 75 (58.2\%) hexaploid, 51 intermediate $(39.5 \%)$ and $3(2.3 \%)$ enneaploid seedlings. Since the distribution of cytotypes in the plots studied was 63: 5: 32, this small study of seedling cytotype is consistent with the idea that cytotype ratio is not stable and is changing toward hexaploid.

This experiment provided the only data I have comparing the contribution of the cytotypes to the next generation as male parents. The 131 seedlings above appear to have received pollen from hexaploids (and/or pollen with a hexaploid cytotype) in 113 cases $(87 \%)$. This is substantially higher than the frequency of hexaploids in the population and suggests an advantage in male fitness by hexaploids as well.

\section{DISCUSSION}

This is the first study to compare individual plants of Andropogon gerardii within natural populations. Across most of the tallgrass prairie, plants are so numerous that individuals are indistinguishable. Most of eastern Colorado is too dry to support tallgrass prairie plants such as A. gerardii, but moisture increases in the foothills of the Rocky Mountains, providing the conditions for a band of tallgrass prairie (Livingston, 1952; Branson et al., 1965; Bock and Bock, 1998). In this tallgrass ecosystem, this study exploited sites where gaps in the cover of A. gerardii allow distinguishing and following individuals to compare individuals with hexaploid and enneaploid chromosome complements.

Hexaploids produced a significantly higher frequency of viable seeds (Figs. 4, 5). Furthermore they reproduced their own cytotype. Enneaploids had lower fertility and rarely produced seeds with their own cytotype. Contrary to my initial expectations, however, many enneaploids were large individuals that produced numerous viable seeds. Clone size and expansion rates did not differ from those of hexaploids. As a group, enneaploids were abundant: they were $35 \%$ of the Andropogon gerardii plants in these plots and provided $31 \%$ of the plant cover by $A$. gerardii.

Two important conclusions emerged. First, higher polyploids contributed genes and individuals to the next generation.

Second, hexaploids were more fit than enneaploids and aneuploids. This has several aspects: (1) hexaploids produced a higher frequency of good seeds. Hexaploids had 4.5 times as many seedlings as enneaploids, from the same spikelet biomass and (2) only hexaploids 
bred true: the seeds produced by enneaploids were rarely enneaploid. Taken together, this indicates that within a few generations, hexaploids will eliminate the other cytotypes.

This conclusion is complicated by the fact that the length of a generation for Andropogon gerardii is unknown. During this four year study a few plants appear to have been recruited into the population (1\%). Of the cytotyped plants, there were 22 deaths in 1199 plant-years of observations, or $1.8 \%$. If this turnover rate is representative and stable, generation time is 50-100 y. Clone areas changed very little over the 4 y (Fig. 1). Elimination of enneaploids and intermediates will probably require decades.

How and when so many enneaploids and intermediates were recruited into the population is also unknown. I hypothesize that when populations are reduced to a few isolated individuals, for example after drought, conditions may permit recruitment odd ploidy levels. Once established, they persist well.

Many grasses contain polyploid series (e.g., Keeler, 1997). No overall theory explains this genetic variation. In some cases, it is certainly a stage in increasing ploidy level and in others a consequence of meiotic errors. Some grasses breed across ploidy levels and the uneven ploidy levels need not be sterile (e.g., Zohary and Nur, 1959; Lumaret, 1988a; Ramsey and Schemske, 1998). Most of the grasses of North American prairie are polyploid (Keeler et al., 1987; Keeler and Kwankin, 1989; Keeler, 1997) and many have intraspecific polyploid cytotypes (Keeler, 1997). Andropogon gerardii is a highly successful species: it dominated the tallgrass prairie ecosystem and beyond that its range extends from the Atlantic Ocean to the Rocky Mountains, from southern Canada to northern Mexico. Odd ploidy levels occurred at least occassionally whereever A. gerardii grows (Keeler, 1990, 1992). This study confirmed that polyploids with low fertility can be big healthy individuals that contribute to the area dominated by the species and to its gene pool.

Acknowledgments. - I thank Jane and Carl Bock for all their help in establishing this project. Barry Bennett provided valuable information on the sites. I thank the City of Boulder Mountain Parks and Open Space staff including Clint Miller, Lynn Reidel and Ann Armstrong for helping me with a variety of logistics. This is project was funded by NSF DEB 9500139, research leave from the University of Nebraska-Lincoln and steady support of the City of Boulder Mountain Parks and Open Space.

\section{Literature Cited}

Arumuganathan, K. and E. D. Earle. 1991. Nuclear DNA content of some important plant species. Plant Mol. Biol. Rep., 9:208-219.

Bennetr, B. C. 1997. Vegetation on the City of Boulder Open Space grasslands. Ph.D. Thesis, University of Colorado, Boulder.

Bever, J. D. And F. Felber. 1993. The theoretical population genetics of autopolyploidy. Oxf. Surv. Evol. Biol., 8:185-217.

Bock, J. H. AND C. E. Bock. 1998. Tallgrass prairie: remnants and relicts. Great Plains Res., 8:213-230.

Boe, A., J. G. Ross and R. Wrnia. 1983. Pedicellate spikelet fertility in big bluestem from eastern South Dakota. J. Range Manag., 36:131-133.

Branson, F. A., R. F. Miller and I. S. McQueen. 1965. Plant communities and soil moisture relationships near Denver, Colorado. Ecology, 46:311-319.

Eberhart, S. A. And L. C. Newell. 1959. Variation in domestic collections of switchgrass Panicum virgatum L. Agron. J., 51:613-616.

ESRI. 1997. ArcView. ESRI Inc., Berkeley, California.

Felber-Girard, M., F. Felber and A. Buttler. 1996. Habitat differentiation in a narrow hybrid zone between diploid and tetraploid Anthoxanthum alpinum. New Phytol., 133:531-540.

Fowler, N. L. AND D. A. Levin. 1984. Ecological constraints on the establishment of a novel polyploid in competition with its diploid progenitor. Am. Nat., 124:703-711.

Hedberg, I. 1967. Cytotaxonomic studies on Anthoxanthum odoratum L s. lat. Symb. Bot. Ups., 18:1-88. 
Hultquist, S. J., K. P. Vogel and S. Kaeppler. 1997. DNA content and chloroplast DNA polymorphisms among switchgrasses from remnant midwestern prairies. Crop. Sci., 37:595.

Husband, B. C. 2000. Constraints on polyploid evolution: a test of the minority cytotype exclusion principle. Proc. Roy. Soc. Lond. Biol. Sci., 267:217-223.

- AND D. W. SChEmSke. 1998. Cytotype distribution at a diploid-tetraploid contact zone in Chamerion (Epilobium) angustifolium (Onagraceae). Am. J. Bot., 85:1688-1694.

KeELER, K. H. 1990. Distribution of polyploids in big bluestem (Andropogon gerardii Poaceae) across the tallgrass prairie region. Genome, 33:95-100.

1992. Local polyploid variation in the native prairie grass Andropogon gerardii. Am. J. Bot., 79:1229-1232.

1997. Population biology of intraspecific polyploidy in grasses, p.183-207. In: G. Cheplick (ed.). Population biology of biology of grasses. Cambridge University Press, Cambridge.

AND B. KWANKIn. 1989. Polyploid polymorphism in the grasses of North American prairie. In: J. H. Bock and Y. B. Linhart (eds.). The evolutionary ecology of plants. Westview Press, Boulder, Colorado.

AND G. L. DAVIs. 1999. Comparison of common cytotypes of Andropogon gerardii (Andropogoneae, Poaceae). Am. J. Bot., 86:974-979.

, B. Kwankin, P. W. Barnes and D. W. Galbratth. 1987. Polyploid polymorphism in Andropogon gerardii. Genome, 29:374-379.

Law, A. G. and K. L. Anderson. 1940. The effect of selection and inbreeding on the growth of big bluestem (Andropogon furcatus Muhl.). Am. J. Bot., 32:931-943.

LEwIS, W. H. 1976. Temporal adapation correlated with polyploidy in Claytonia virginica. Syst. Bot., 1: 340-347.

1980. Polyploidy: biological relevance. Plenum, New York, New York.

Livingston, R. B. 1952. Relict true prairie communities in central Colorado. Ecology, 33:72-86.

Lumaret, R. 1988a. Adaptive strategies and ploidy levels. Acta Oecol. Plant., 9:83-93.

. 1988b. Cytology, genetics and evolution in the genus Dactylis. Crit. Rev. Plant Sci., 7:55-91.

AND E. BarRIEnTos. 1990. Phylogenetic relationships and gene flow between sympatric diploid and tetraploid plants of Dactylis glomerata (Gramineae). Plant Syst. Evol., 169:81-96.

Masters, R. A., R. B. Mitchell, K. P. Vogel and S. S. Waller. 1993. Influence of improvement practices on big bluestem and indiangrass seed production in tallgrass prairies. J. Range Manag., 46: 183-188.

McKone, M. J., C. P. Lund And J. M. O’Brien. 1998. Reproductive biology of two dominant prairie grasses (Andropogon gerardii and Sorghastrum nutans, Poaceae): male-biased sex allocation in wind pollinated plants? Am. J. Bot., 85:776-783.

MCMillan, C. 1959. The role of ecotypic variation in the distribution of the central grassland of North America. Ecol. Monogr., 29:286-308.

Michaelson, M. J., H. J. Price, J. R. Ellison and J. S. Johnston. 1991. Comparison of plant DNA contents determined by Feulgen microspectrophotometry and laser flow cytometry. Am. J. Bot., 78: 590-593.

Nielsen, E. L. 1944. Analysis of variation in Panicum virgatum. J. Agric. Res., 69:327-353.

. 1947. Polyploidy and winter survival in Panicum virgatum L. J. Am. Soc. Agron., 39:822-827.

Norrmann, G. A. AND K. H. Keeler. 2003. Cytotypes of Andropogon gerardii Vitman (Poaceae): fertility and reproduction of aneuploids. Biol. J. Linn. Soc., 141:95-103.

, C. A. Quarín and B. L. Burson. 1989. Cytogenetics and reproductive behavior of different chromosome races in six Paspalum species. J. Hered., 80:24-28.

— - - AND K. H. KeELER. 1997. Evolutionary implications of meiotic chromosome behavior, reproductive biology and hybridization in 6x and 9x cytotypes of Andropogon gerardii (Poaceae). Am. J. Bot., 84:201-207.

PorTer, C. L. J. 1966. An analysis of variation between upland and lowland switchgrass Panicum virgatum L in central Oklahoma. Ecology, 47:980-992.

Quarín, C. A. and A. Fernández. 1982. Genetic studies in diploid and tetraploid Paspalum species. J. Hered., 76:254-256. 
Ramsey, J. and D. W. Schemske. 1998. Pathways, mechanisms and rates of polyploid formation in flowering plants. Annu. Rev. Ecol. Syst., 29:467-501.

Riley, R. D. ANd K. P. Vogel. 1982. Chromosome numbers of released cultivars of switchgrass, indiangrass, big bluestem and sand bluestem. Crop. Sci., 22:1081-1083.

Rodríguez, D. J. 1996a. A model for establishment of polyploidy in plants. Am. Nat., 147:33-46.

. 1996b. A model for the establishment of polyploidy in plants: viable but infertile hybrids, iteroparity, and demographic stochasticity. J. Theor. Biol., 180:189-196.

Rothera, S. L. ANd A. J. Davy. 1986. Polyploidy and habitat differentiation in Deschampsia caespitosa. New Phytol., 102:449-467.

SAS Institute Inc. 1999. StatView Statistical Program. SAS Institute Inc, Cary, North Carolina.

Snetselaar, K. M. and L. H. Tiffany. 1990. Diseases of big bluestem caused by smut fungi. Proc. 12th N. Am. Prairie Conf., 1-3.

SPRINGER, T. L. 1991. Caryopsis size and germination of Andropogon gerardii pedicellate and sessile spikelets. Seed Sci. Tech., 19:461-468.

SveJCAR, T. J. 1990. Response of Andropogon gerardii to fire in the tallgrass prairie, p. 19-27. In: S. L. Collins and L. L. Wallace (eds.). Fire in North American tallgrass prairies. University Oklahoma Press, Norman, Oklahoma.

Weaver, J. E. and T. J. Fitzpatrick. 1934. The prairie. Ecol. Monogr., 4:109-295.

Zohary, D. And U. Nur. 1959. Natural triploids in the orchard grass Dactylis glomerata L. polyploid complex, and their significance for gene flow from diploid to tetraploid levels. Evolution, 13:311-317. 